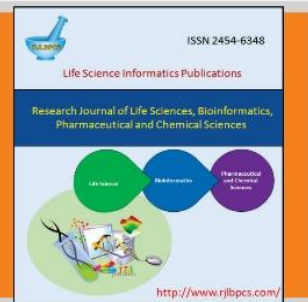

Life Science Informatics Publications

Research Journal of Life Sciences, Bioinformatics, Pharmaceutical and Chemical Sciences

Original Research Article

DOI: $10.26479 / 2020.0605 .07$

COMPLEXOMETRIC DETERMINATION OF ZINC USING HYDROXYTRIAZENE AS A METALLOCHROMIC INDICATOR

\title{
Ochieng Ombaka
}

Department of Physical Sciences, Chuka University, 109-60400, Chuka, Kenya.

\begin{abstract}
New metallochromic indicators belonging to the class of hydroxytriazenes has been evaluated for the direct complexometric determination of Zinc in the presence of diverse ions. Reagent no (i), (ii) and (iii) has been found to be excellent indicators in the titration with EDTA at $\mathrm{pH} 6.95-7.50,6.90-7.60$ and 7.00-7.50 respectively. The colour at the end point was from light green to colourless and the titration was carried out between temperature range of $20-60^{\circ} \mathrm{C} . \mathrm{Cl}^{-}$, $\mathrm{Br}^{-}, \mathrm{CH}_{3} \mathrm{COO}^{-}, \mathrm{CO}_{3}{ }^{2-}, \mathrm{SO}_{4}{ }^{2-}, \mathrm{NO}_{2}^{-}, \mathrm{SO}_{3}{ }^{2-}, \mathrm{F}^{-}, \mathrm{NO}_{3}{ }^{-}, \mathrm{I}^{-}, \mathrm{S}^{2-}, \mathrm{WO}_{4}{ }^{2-}, \mathrm{MO}_{7} \mathrm{O}_{24}{ }^{6-}, \mathrm{NH}_{4}{ }^{+}, \mathrm{Na}^{+}, \mathrm{K}^{+}, \mathrm{U}(\mathrm{VI})$, $\mathrm{Mn}(\mathrm{II}), \mathrm{Ba}(\mathrm{II}), \mathrm{Hg}(\mathrm{II}), \mathrm{Sn}(\mathrm{II}), \mathrm{Cd}(\mathrm{II}), \mathrm{Mg}(\mathrm{II}), \mathrm{Ca}$ (II), $\mathrm{Zr}$ (IV) can be tolerated in the titration of zinc (II) when they are present in equivalent amount with that of zinc (II). However, $\mathrm{PO}_{4}{ }^{3-}, \mathrm{Co}$ (II), $\mathrm{Cu}$ (II) and Ni (II) interferes and when present in the environmental samples, separation techniques such as masking and demasking agents must be employed. The utility of the technique was checked by using 3-Hydroxy-3-m-toly-1-0-Carboxyphenyltriazene for estimation of zinc in zinc-copper alloy and the results had a maximum relative error of +1.53 and standard deviation of \pm 0.0378 using Sodium thiosulphate to mask copper ions, hence the study clearly indicated that reagent no (i) and (ii) which have high sensitivity, high selectivity and fairly a wide $\mathrm{pH}$ range can be used as metallochromic indicators for estimation of zinc in environmental sample where zinc is the major element.
\end{abstract}

Keywords: Complexometric, metallochromic indicators, Zinc, EDTA, Interfering species.

Article History: Received: September 05, 2020; Revised: September 20, 2020; Accepted: October 02, 2020.

\section{Corresponding Author: Dr. Ochieng Ombaka* Ph.D.}

Department of Physical Sciences, Chuka University, 109-60400, Chuka, Kenya.

Email Address: ombakaochieng@gmail.com

(C) 2020 Life Science Informatics Publication All rights reserved

Peer review under responsibility of Life Science Informatics Publications

2020 Sept - Oct RJLBPCS 6(5) Page No.77 


\section{INTRODUCTION}

Zinc is used in galvanizing steel [1], preventing corrosion [2,3], coatings [4,5] or as alloying element in brass, aluminum, bronzes [6,7,8] and magnesium alloys [9,10,11,12,13]. Further its being exploited as oxide in chemical, pharmaceutical, cosmetics, paint, rubber and also in the construction field for the production of roofing, downspouts, gutters, parts of the lamps, flashlight reflectors etc. [14]. The primary anthropogenic sources of zinc in the environment come from mining and smelters activities. The production and utilization of zinc in brass, bronze, die castings metal, alloys, rubbers and paints may contribute to its release to the environment through various waste streams. The major dietary source of zinc in adults includes: meats, dairy products, grains and mixed dishes. Zinc plays essential roles for the function of more than 300 enzymes such as alkaline phosphatase, alcohol dehydrogenase etc. [15]. The deficiency in humans causes bullous pustular dermatitis, diarrhea, alopecia, mental disturbances and impaired cell-mediated immunity resulting in intercurrent infections while moderate zinc deficiency contributes to growth retardation, male hypogonadism, skin changes, poor appetite, mental lethargy, abnormal dark adaptation and delayed wound healing. The individual with mild or marginal zinc deficiency can suffer from neurosensory, impaired neuropsychological functions, oligospermia, decreased serum testosterone, hyperammonemia and impaired immune function [16]. Excess of zinc causes short term "metal-fume fever", nausea, diarrhea, depression, lethargy and neurological signs. Moreover, zinc accumulates in nature and cannot be biodegraded [17]. Zinc is involved in a number of physiological functions and its deficiencies can affect plant by stunting its growth, decreasing number of tillers, chlorosis and smaller leaves, increasing crop maturity period, spikelet sterility and reduced crop yields [18]. Excess of $\mathrm{Zn}^{2+}$ in plants prompts negative interferences with other nutrients uptake and enzyme activities, elicits wilting, necrosis of old leaves, biomass decline and inhibition of cell elongation and division. The passing of zinc threshold or toxicity is due to industrial and agricultural activities like smelter and incinerator emissions, disposal from mine wastes, excessive application of zinc containing fertilizers or pesticides and use of zinc contaminated sewage sludges, manures or industrial wastes as fertilizers [19]. Therefore, there is a need for simple, selective, sensitive, rapid and accurate analytical technique for the determination of zinc in the environmental samples. The techniques widely used for zinc determination are flame atomic absorption spectrophotometry, atomic emission spectrometry, inductively-coupled plasma spectroscopy, graphite furnace atomic absorption spectroscopy, x-ray fluorescence and titrimetric. Among these methods titrimetric techniques approaches are attractive due to the advantages associated with the techniques which includes saving time and labour, high precision, no need for the use of reference standards [20]. The principal titrimetric techniques for quantitative analysis of the zinc (II) involves the use of EDTA with Eriochrome Black T indicator, (xylenol or methyl thymol blue) indicators at pH 10.0, 6.0 respectively, are not free from interferences. In the literature it has been reported that, $\mathrm{Mg}, \mathrm{Mn}, \mathrm{Cd}$,

(C) 2020 Life Science Informatics Publication All rights reserved

Peer review under responsibility of Life Science Informatics Publications 
$\mathrm{Hg}$ and $\mathrm{Pb}$ interferes with the determination of zinc when Eriochrome Black $\mathrm{T}$ is used as metallochromic indicator and EDTA as a titrant at $\mathrm{pH} 10$. When xylenol orange is used as indicator with EDTA as titrant at $\mathrm{pH}$ range of 1-2, Bi, Th, Co interferes with zinc determination. This implies that for titration of mixtures using reported metallochromic indicators will require selective masking and demasking approach [21]. However, the use of masking agent sometimes contributes to the visual end points to be degraded [22]. Therefore, there is a need to explore the possibility of searching a metallochromic indicator which can be used in the presence of foreign ions without being interfered with. The literature review reveals that hydroxytriazenes as a metallochromic indicators does not suffer from interference from most of cations and anions [23]. The determination of zinc in pharmaceutical samples using hydroxytriazene has been reported in the literature [24]. Therefore, the present study pertains searching for hydroxytriazene which can be used as metallochromic indicator in presence of foreign ions without using masking and demasking or any kind of separation technique approach while determining zinc in environmental samples.

\section{MATERIALS AND METHODS}

\section{Apparatus, Chemicals and Reagents}

Ultra-pure water equipment (model MILLI-Q equipped with Q-POD), pH meter (HI 2211 pH /OR meter) HANNA instruments, glass Wares, Analytical grade chemicals, Ultra-pure water.

\section{Preparation of Solutions}

\section{Preparation of Standard Solution of $0.01 M \mathrm{Zn}^{2+}$}

The required quantity of zinc acetate dihydrate was dissolved in ultra-pure water and few drops of glacial acetic acid were added to prevent hydrolysis. The solution was then standardized gravimetrically with 8-hydroxyquinaldine generated by the hydrolysis of 8 -acetoxyquinaldine at $\mathrm{pH}$ 4.4 and temperature between $60-70^{\circ} \mathrm{C}$ followed by washing the precipitate. The precipitate was then dried at $105-110^{\circ} \mathrm{C}$ and weighed using analytical balance [25].

\section{Standard Solutions of 0.01M EDTA}

The appropriate amount of disodium salt of EDTA which was initially dried at $80^{\circ} \mathrm{C}$ was dissolved in ultra-pure water up to known volume and standardized against zinc acetate dehydrate solution $(0.01 \mathrm{M})$ using xylenol orange indicator [26].

\section{Xylenol Orange Indicator (0.1 \%)}

$0.1 \mathrm{~g}$ of Xylenol orange was dissolved in $100 \mathrm{ml}$ of ultra-pure water and filtered.

\section{Hydroxytriazene Indicator $(0.1 \%)$}

$0.1 \mathrm{~g}$ of each hydroxytriazene was dissolved in $100 \mathrm{ml}$ ethanol [reagent no (i) to (iii)] and $100 \mathrm{ml}$ acetone [reagent no. (iv) and (v)].

\section{Hexamine Solution (1.0\%)}

$1.0 \mathrm{~g}$ of Hexamine was dissolved in minimum amount of ultra-pure water and then made up to 100 mark using ethanol for reagent no (i) to (iii) and acetone for reagent no. (iv) and (v).

(C) 2020 Life Science Informatics Publication All rights reserved Peer review under responsibility of Life Science Informatics Publications 


\section{Perchloric Acid Solution (1.0\%)}

$1.0 \mathrm{ml}$ of Perchloric acid was diluted up to 100 mark with ethanol for reagent (i) to (iii) and acetone for reagent (iv) and (v).

\section{Diverse Ions Solution}

The solutions were prepared by dissolving the required quantities of various cations and anions salt in ultra-pure water or in suitable diluted acids and then diluted to known volume.

\section{Zinc-Copper Alloy (Code: Zn-Cu-01-P.05 Cu, Purity: (5N) 99.999\%) Dissolution}

$68.821 \mathrm{mg}$ of zinc-copper alloy was reacted with $5 \mathrm{ml}$ of concentrated nitric acid (70\%) in a hood. After complete dissolution, the resulting solution was diluted in a $100 \mathrm{ml}$ volumetric flask.

\section{Procedure}

\section{Synthesis of Hydroxytriazenes}

The synthesis of hydroxytriazenes followed three steps which included reduction of aryl nitrobenzene to aryl hydroxyl amine, diazotization of aryl amine to diazonium salt and coupling aryl hydroxyl amine and diazonium salt at $\mathrm{pH}$ around 6.0 while maintaining the temperature between 0 $5^{\circ} \mathrm{C}[27]$. The synthesized compounds were:

i. 3-Hydroxy-3-m-tolyl-1-p-methoxyphenyltriazene, $\mathrm{C}_{14} \mathrm{H}_{15} \mathrm{~N}_{3} \mathrm{O}_{2}$

ii. 3-Hydroxy-3-m-tolyl-1-0-Carboxyphenyltriazene, $\mathrm{C}_{14} \mathrm{H}_{13} \mathrm{~N}_{3} \mathrm{O}_{3}$

iii. 3-Hydroxy-3-0-tolyl-1-0-carboxyphenyltriazene, $\mathrm{C}_{14} \mathrm{H}_{13} \mathrm{~N}_{3} \mathrm{O}_{3}$

iv. 3-Hydroxy-3-m-tolyl-1-0-nitrophenyltriazene, $\mathrm{C}_{13} \mathrm{H}_{12} \mathrm{~N}_{4} \mathrm{O}_{3}$

v. 3-Hydroxy-3-m-tolyl-1-p-nitrophenyltriazene. $\mathrm{C}_{13} \mathrm{H}_{12} \mathrm{~N}_{4} \mathrm{O}_{3}$

Ethanol or acetone was used for recrystallization of hydroxytriazenes. The selection of the solvent relied on the fact that, hydroxytriazene was insoluble in the selected solvent at room temperature and its solubility increases as the temperature of the solvent was being increased. Further the impurities which were present were soluble in the solvent at room temperature and insoluble at high temperature. Recrystallization was repeated until the hydroxytriazenes melted over a narrow range of temperature which did not change with further recrystallization. The temperature at which the compound just started to melt was taken as the melting point. The spot tests used for detection of hydroxytriazenes were as follows: $\alpha$-Naphthylamine test, Picric acid test, N, N-dimethylaniline test and sulphuric acid test.

\section{Preliminary Studies}

The screening of each hydroxytriazenes synthesized as metallochromic indicator for $\mathrm{Zn}$ (II) determination involved taking $10 \mathrm{ml}$ of $1.0 \times 10^{-2} \mathrm{M}$ Zinc (II) solution and titrate it against equimolar solution of EDTA in $\mathrm{pH}$ range 6.0-8.0. The $\mathrm{pH}$ was adjusted using 1.0\% Hexamine and 1.0\% Perchloric acid solutions.

\section{Effect of pH Variation}

The effect of $\mathrm{pH}$ variation on the determination of Zinc (II) content was studied by performing the

(C) 2020 Life Science Informatics Publication All rights reserved

Peer review under responsibility of Life Science Informatics Publications

2020 Sept - Oct RJLBPCS 6(5) Page No.80 
titration at various $\mathrm{pH}$ at a constant concentration using 1.0\% Hexamine and 1.0\% Perchloric acid solutions for adjusting the $\mathrm{pH}$. The Optimum $\mathrm{pH}$ range was determined where the colour change at the end point was sharp and most perceptible.

\section{Effect of Temperature}

The effect of temperature was studied by titrating $1 \times 10^{-2} \mathrm{M} \mathrm{Zn}$ (II) ions against equimolar EDTA solution under optimum conditions of solvent and $\mathrm{pH}$ with hydroxytriazene as metallochromic indicator at different temperatures.

\section{Optimum Concentration Range of Zn (II)}

The effect of changing concentration was studied in order to obtain the minimum concentration of Zinc (II) that could be satisfactorily titrated using each of hydroxytriazenes in order to obtain perceptible end point. This was done by titrating different concentrations of Zinc (II) against equimolar solution of EDTA.

\section{Interference Studies}

The study of interference of 34 diverse ions in Complexometric determination of Zinc (II) using each hydroxytriazene as metallochromic indicator was carried out in order to establish how selective they are. This involved titrating $3.2685 \mathrm{mgs}$ of Zinc (II) against equimolar EDTA in presence of various amount of interfering species under optimum conditions using hydroxytriazenes as indicator.

\section{Titration Procedure}

A $10 \mathrm{ml}$ of zinc (II) solution was diluted to $30 \mathrm{ml}$ with ethanol-water or acetone-water mixture depending on the solubility of indicator. The $\mathrm{pH}$ was adjusted using 1.0\% Hexamine solution and $1.0 \%$ Perchloric acid solution. Five to six drops of hydroxytriazene were added which resulted in instantaneous development of yellow colour. The solution was titrated very slowly with equimolar solution of EDTA at room temperature. Close to the end point, one or two drops of indicator were further added to this solution to enhance the perceptibility of the end point. The point where the colour sharply changed to colourless was recorded as the end point in all the cases. These results were compared with the results obtained using Xylenol orange as indicator.

\section{Complexometric titration of sample alloy using 3-Hydroxy-3-m-tolyl-1-0- carboxyphenyltriazene as metallochromic indicator}

$10 \mathrm{ml}$ of alloy solution was pipetted in a conical flask. $1.0 \%$ hexamine solution and Perchloric acid solution were used to adjust the $\mathrm{pH}$ of the alloy solution in a conical flask to be between 6.95 and 7.50. Thereafter, sodium thiosulphate was added to the solution in order to complexes selectively the $\mathrm{Cu}^{2+}$ ions. This was followed by adding 5 to 6 drops of hydroxytriazene indicator. This solution was slowly titrated at room temperature with $0.01 \mathrm{M}$ EDTA. Close to the end point, one or two drops of indicator were further added so as to enhance the perceptibility of the end point. 


\section{RESULTS AND DISCUSSION}

The general strategy shown above was employed in preparation of five hydroxytriazenes. All these compounds gave positive test with all the four spot tests. The compounds were confirmed by physical properties and elemental analysis data listed in Table1.

Tables 1: Physical Characteristics and Elemental analysis of hydroxytriazenes

\begin{tabular}{|c|c|c|c|c|c|c|c|}
\hline $\begin{array}{l}\text { Reagent } \\
\text { No. }\end{array}$ & $\begin{array}{l}\text { Colour and shape of } \\
\text { crystal }\end{array}$ & $\begin{array}{l}\text { Crystallized } \\
\text { from }\end{array}$ & M.P ${ }^{\circ} \mathrm{C}$ & & $\% \mathrm{C}$ & $\% \mathrm{H}$ & $\% \mathrm{~N}$ \\
\hline \multirow[t]{2}{*}{ (i) } & \multirow{2}{*}{$\begin{array}{l}\text { Light yellow } \\
\text { shinning needles }\end{array}$} & \multirow[t]{2}{*}{ Ethanol } & \multirow[t]{2}{*}{112} & $\mathrm{Th}$ & 65.33 & 5.86 & 16.34 \\
\hline & & & & Exp. & 64.56 & 5.77 & 16.87 \\
\hline \multirow[t]{2}{*}{ (ii) } & \multirow{2}{*}{$\begin{array}{l}\text { Light yellow } \\
\text { shinning needles }\end{array}$} & \multirow[t]{2}{*}{ Ethanol } & \multirow[t]{2}{*}{178} & Th & 61.96 & 4.83 & 15.49 \\
\hline & & & & Exp. & 61.44 & 4.69 & 14.66 \\
\hline \multirow[t]{2}{*}{ (iii) } & \multirow{2}{*}{$\begin{array}{l}\text { Light yellow } \\
\text { shinning needles }\end{array}$} & \multirow[t]{2}{*}{ Ethanol } & \multirow[t]{2}{*}{138} & $\mathrm{Th}$ & 61.96 & 4.83 & 15.49 \\
\hline & & & & Exp. & 60.48 & 4.63 & 14.89 \\
\hline \multirow[t]{2}{*}{ (iv) } & \multirow[t]{2}{*}{ Deep yellow powder } & \multirow[t]{2}{*}{ Acetone } & \multirow[t]{2}{*}{128} & $\mathrm{Th}$ & 57.32 & 4.44 & 20.53 \\
\hline & & & & Exp. & 57.74 & 4.26 & 18.78 \\
\hline \multirow[t]{2}{*}{ (v) } & \multirow[t]{2}{*}{ Light yellow powder } & \multirow[t]{2}{*}{ Acetone } & \multirow[t]{2}{*}{180} & Th & 57.32 & 4.44 & 20.58 \\
\hline & & & & Exp. & 56.33 & 4.87 & 20.63 \\
\hline
\end{tabular}

The colour and the shape of crystals of hydroxytriazenes were light yellow (reagent no. (i) to (iii)), deep yellow powder (reagent iv) and light-yellow powder (reagent v). The yellow colour of these compounds shows that, these compounds absorb light in the visible region, possess at least one chromophore, have a conjugated system and exhibit resonance of electrons. The process of crystallization which control physical properties, yield and purity of a compound was performed. The melting point being a physical property of a substance was determined for each hydroxytriazenes in order to identify and establish the purity of these hydroxytriazenes. The result from table 1 showed that reagent no (v) have the highest melting point indicating that it has a stronger intermolecular force compared to other four hydroxytriazenes. The contents of carbon, Hydrogen and Nitrogen in each of hydroxytriazenes in table 1, showed, experimental and theoretical data are in good agreement. The results of preliminary studies are presented in table 2.

Conc. of $\mathrm{Zn}$ (II) solution $=5.0 \times 10^{-3} \mathrm{M}$

Conc. of EDTA solution $=5.0 \times 10^{-3} \mathrm{M}$

Volume of $\mathrm{Zn}$ (II) solution taken $=10.0 \mathrm{ml}$

Volume of EDTA consumed when using Xylenol orange $=10.0 \mathrm{ml}$

(C) 2020 Life Science Informatics Publication All rights reserved

Peer review under responsibility of Life Science Informatics Publications 
Table 2: Preliminary studies

\begin{tabular}{|c|c|c|c|}
\hline $\begin{array}{l}\text { Reagent } \\
\text { No. }\end{array}$ & Colour change at the end point & $\begin{array}{l}\text { Volume of EDTA } \\
\text { consumed }(\mathrm{ml})\end{array}$ & Remark \\
\hline (i) & Light yellow to colorless & 10.0 & Very sharp end point \\
\hline (ii) & Light yellow to colorless & 10.0 & Very sharp end point \\
\hline (iii) & Light yellow to colorless & 10.0 & Sharp end point \\
\hline (iv) & $\begin{array}{l}\text { No change in colour even when } \\
\text { excess of EDTA was added }\end{array}$ & - & Not suitable \\
\hline (v) & $\begin{array}{l}\text { No change in colour even when } \\
\text { excess of EDTA was added }\end{array}$ & - & Not suitable \\
\hline
\end{tabular}

These results reveal that, hydroxytriazenes no (i) to (iii) exhibit a drastic change at the end point which resulted in obtaining accurate results, hence they can be used as metallochromic indicators [28]. The results were comparable to those of xylenol orange indicator. The use of direct titration to obtain accurate results clearly demonstrated that, the zinc-EDTA complex was more stable, followed by the zinc-hydroxytriazene in a weakly acidic solution. The sequences which took place during titration were as follows: EDTA displaced the;

1) Zinc ions from the hexamine complex

2) Zinc ions from the hydroxytriazenes complex

3) The EDTA binded all the zinc which had dissociated from the hydroxytriazenes, marking the end of titration.

The choice of hexamine buffer was due to its weak interaction with zinc ions which has advantage to the stability of zinc-EDTA complex [29]. The complexes formed between zinc and reagent no (i), (ii) and (iii) have $\log _{10} \beta$ of $10.0346,5.5974,5.1962$ respectively [30], while $\log _{10} \beta$ of zincEDTA is $16.440[31]$. These results of $\log _{10} \beta$ clearly supports the sequences given above. The colour change for reagent no. (i) to (iii) was from light yellow to colourless with a very sharp end point. However, reagent no. (iv) and (v) were found not suitable to be employed as metallochromic indicator. The sensitivity for reagent no. (i) to (iii) was investigated by determining optimum concentration range of zinc (II) when using EDTA as a titrant and hydroxytriazenes as metallochromic indicators. The results obtained have been summarized in table 3 . 
Table 3: Optimum concentration Range of Zinc (II)

\begin{tabular}{|c|c|c|c|c|c|c|}
\hline \multicolumn{3}{|c|}{$\begin{array}{l}\text { Concentration of zinc (II) ions } \\
\text { Concentration of EDTA }\end{array}$} & $\begin{array}{l}1.0 \times 10^{-2} \mathrm{M} \\
1.0 \times 10^{-2} \mathrm{M}\end{array}$ & $\begin{array}{l}5.0 \times 10^{-3} \\
5.0 \times 10^{-3}\end{array}$ & $\begin{array}{l}2.0 \times 10^{-3} \mathrm{M} \\
2.0 \times 10^{-3} \mathrm{M}\end{array}$ & $\begin{array}{r}1.0 \times 10^{-3} \mathrm{M} \\
1.0 \times 10^{-3} \mathrm{M}\end{array}$ \\
\hline $\begin{array}{l}\text { Reagent } \\
\text { no. }\end{array}$ & $\begin{array}{l}\mathrm{pH} \text { range of } \\
\text { the titration }\end{array}$ & $\begin{array}{l}\text { Temp. of } \\
\text { the } \\
\text { titration } \\
{ }^{0} \mathrm{C}\end{array}$ & \multicolumn{4}{|c|}{ Titre Value in $\mathrm{ml}$} \\
\hline (i) & $6.95-7.50$ & $20-60$ & 10.0 & 10.0 & 10.0 & 8.0 \\
\hline (ii) & $6.90-7.60$ & $20-60$ & 10.0 & 10.0 & 10.0 & 9.8 \\
\hline (iii) & $7.09-7.50$ & $20-60$ & 10.0 & 10.0 & 9.8 & - \\
\hline
\end{tabular}

Volume of zinc (II) ions taken $=10 \mathrm{ml}$

The results revealed that, Zinc (II) ions can be determined accurately using reagent no (i) and (ii) as metallochromic indicator up to the concentrations as low as $2.0 \times 10^{-3} \mathrm{M}$ at $\mathrm{pH}$ range of $6.95-7.50$ (reagent no (i)), 6.90-7.60(reagent no (ii)) and temperature range of $20-60^{\circ} \mathrm{C}$. The results revealed that reagent no (i) and (ii) have fairly high sensitivity compared to (iii). However, reagent no (ii) have fairly a wide pH range compared to reagent no (i) and (iii). The effect of the presence of diverse ions on the accuracy of the zinc determination was studied by carrying out the determination of $3.2685 \mathrm{mgs}$ of zinc (II) ions. The interferences were studied at three levels. It was observed that 13 ions, viz: $\mathrm{Cl}^{-}, \mathrm{Br}^{-}, \mathrm{CH}_{3} \mathrm{COO}^{-}, \mathrm{CO}_{3}{ }^{2-}, \mathrm{SO}_{4}{ }^{2-}, \mathrm{NO}_{2}^{-}, \mathrm{SO}_{3}{ }^{2-}, \mathrm{F}^{-}, \mathrm{NO}_{3}^{-}, \mathrm{I}^{-}, \mathrm{NH}_{4}{ }^{+}, \mathrm{Na}^{+}, \mathrm{K}^{+}$were tolerated when added in tenfold excess of zinc. However, ions such as $\left(\mathrm{PO}_{4}{ }^{3-}, \mathrm{Co}(\mathrm{II}), \mathrm{Cu}(\mathrm{II}), \mathrm{Ni}(\mathrm{II})\right),\left(\mathrm{C}_{2} \mathrm{O}_{4}{ }^{2-}\right.$, $\left.\mathrm{S}_{2} \mathrm{O}_{4}{ }^{2+}, \mathrm{HPO}_{2}{ }^{2-}, \mathrm{Pb}(\mathrm{II}), \mathrm{Th}(\mathrm{IV})\right), \mathrm{S}^{2-}, \mathrm{WO}_{4}{ }^{2-}, \mathrm{MO}_{7} \mathrm{O}_{24}{ }^{6-}, \mathrm{U}(\mathrm{VI}), \mathrm{Mn}(\mathrm{II}), \mathrm{Ba}(\mathrm{II}), \mathrm{Hg}(\mathrm{II}), \mathrm{Sn}(\mathrm{II}), \mathrm{Cd}(\mathrm{II})$, $\mathrm{Mg}(\mathrm{II}), \mathrm{Ca}(\mathrm{II}), \mathrm{Zr}(\mathrm{IV})$ ) were not tolerated when added in equivalent amounts, fivefold excess and tenfold excess as shown in tables 4,5 and 6 respectively.

Table 4: Interference Studies at Equivalent Amount

\begin{tabular}{lllll}
\hline \multirow{2}{*}{ Reagent No } & \multicolumn{4}{l}{ Foreign ions } \\
\cline { 2 - 4 } & $\mathrm{PO}_{4}{ }^{3-}$ & $\mathrm{Co}(\mathrm{II})$ & $\mathrm{Cu}(\mathrm{II})$ & $\mathrm{Ni}(\mathrm{II})$ \\
\cline { 2 - 4 } & \multicolumn{4}{l}{ Volume of EDTA consumed in $\mathrm{ml}$} \\
\hline (i) & 9.8 & 10.6 & 10.3 & 14.7 \\
(ii) & 9.6 & 10.7 & 10.4 & 10.5 \\
(iii) & 9.3 & 10.6 & 12.3 & 10.4 \\
\hline
\end{tabular}

(C) 2020 Life Science Informatics Publication All rights reserved Peer review under responsibility of Life Science Informatics Publications 2020 Sept - Oct RJLBPCS 6(5) Page No.84 
Table 5: Interference studies at five-fold excess

\begin{tabular}{llllll}
\hline Reagent No & \multicolumn{5}{l}{ Foreign ions } \\
\cline { 2 - 5 } & $\mathrm{C}_{2} \mathrm{O}_{4}{ }^{2-}$, & $\mathrm{S}_{2} \mathrm{O}_{3}{ }^{2-}$, & $\mathrm{HpO}_{4}{ }^{2-}$ & $\mathrm{Pb}(\mathrm{II})$ & $\mathrm{Th}(\mathrm{IV})$, \\
\cline { 2 - 5 } & \multicolumn{5}{l}{ Volume of EDTA consumed in $\mathrm{ml}$} \\
\hline (i) & 9.5 & 9.7 & 9.0 & 10.6 & 12.3 \\
(ii) & 9.4 & 8.9 & 8.3 & 10.8 & 10.5 \\
(iii) & 8.3 & 9.8 & 6.3 & 10.3 & 10.3 \\
\hline
\end{tabular}

Table 6: Interference studies at tenfold excess

\section{Reagent Foreign ions}

$\begin{array}{lllllllllllll}\text { No. } & \mathrm{S}^{2-} & \mathrm{WO}_{4}{ }^{2-} & \mathrm{MO}_{7} \mathrm{O}_{24}{ }^{6-} & \mathrm{U}(\mathrm{VI}) & \mathrm{Mn}(\mathrm{II}) & \mathrm{Ba}(\mathrm{II}) & \mathrm{Hg}(\mathrm{II}) & \mathrm{Sn}(\mathrm{II}) & \mathrm{Cd}(\mathrm{II}) & \mathrm{Mg}(\mathrm{II}) & \mathrm{Ca}(\mathrm{II}) & \mathrm{Zr}(\mathrm{IV})\end{array}$

Volume of EDTA consumed in ml

(i)

$\begin{array}{rrrrrrrrrrrrr}8.8 & 9.7 & 9.7 & 10.7 & 10.4 & 10.3 & 10.2 & 13.1 & 10.9 & 10.3 & 10.4 & 10.7 \\ 9.1 & 9.8 & 9.6 & 11.0 & 10.8 & 10.2 & 10.7 & 11.7 & 11.0 & 10.2 & 10.4 & 10.6 \\ & & & & & & & & & & & \\ 9.4 & 9.8 & 9.7 & 14.2 & 10.4 & 10.2 & 10.2 & 11.0 & 11.8 & 10.5 & 10.7 & 10.9\end{array}$

Examination of these tables revealed that, cations interfered with positive errors when each of hydroxytriazenes was used as metallochromic indicators while anions interfered with negative errors. The interferences of cations were attributed to competing for titrant between zinc ions and interfering species while the negative interferences of anions were attributed to the formation of complex between zinc ions and anions, hence reducing the amount of zinc ions available to be titrated with EDTA. However, the interference of these ions can be prevented by using masking and demasking agents, for example $\mathrm{Cu}^{2+}$ ions can be prevented by adding a solution of Sodium thiosulphate which reduces $\mathrm{Cu}$ (II) to $\mathrm{Cu}$ (I). $\mathrm{Cu}$ (I) does not bind to EDTA.

$2 \mathrm{Cu}^{2+}+2 \mathrm{~S}_{2} \mathrm{O}_{3}{ }^{2-} \rightarrow 2 \mathrm{Cu}^{+}+\mathrm{S}_{4} \mathrm{O}_{6}{ }^{2-}$

The cadmium can be masked by using $50 \% \mathrm{w} / \mathrm{v} \mathrm{KI}$.

\section{Application}

In order to explore the usefulness of the proposed technique, quantitative analysis of zinc in zinccopper alloy was carried out using reagent (II) which had fairly large $\mathrm{pH}$ range compared to other hydroxytriazenes. The analytical results of alloy samples are entered in Table 7.

(C) 2020 Life Science Informatics Publication All rights reserved Peer review under responsibility of Life Science Informatics Publications 2020 Sept - Oct RJLBPCS 6(5) Page No.85 
Table 7: Estimation of Zinc-copper

\begin{tabular}{|c|c|c|c|c|c|}
\hline S/No & $\mathrm{S}_{1}$ & $\mathrm{~S}_{2}$ & $\mathrm{~S}_{3}$ & $\mathrm{~S}_{4}$ & $\mathrm{~S}_{5}$ \\
\hline Amount of Zinc present in alloy taken (mg) & 6.54 & 6.54 & 6.54 & 6.54 & 6.54 \\
\hline Amount of Zinc found to be present (mg) & 6.64 & 6.61 & 6.56 & 6.55 & 6.57 \\
\hline Relative error (\%) & +1.53 & +1.07 & +0.31 & +0.15 & +0.48 \\
\hline
\end{tabular}

The results in table 7 shows that the maximum relative error was +1.53 with standard deviation of \pm 0.0378 , hence, the proposed technique is fairly accurate and precise.

\section{CONCLUSION}

The three hydroxytriazenes used as indicators are fairly selective, sensitive and can be used as metallochromic indicators in the presence of a number of cations and anions at equivalent amount. $\mathrm{PO}_{4}^{3-}, \mathrm{Co}^{2+}, \mathrm{Cu}^{2+}$ and $\mathrm{Ni}^{2+}$ interferes with the zinc determination when they are present at equivalent amount. The absence of adverse effect of many cations and anions on the accuracy and precision of the technique when present at equivalent amounts shows that, the proposed technique can be utilized for the determination of zinc in its alloys, complexes and environmental samples. However, when $\mathrm{PO}_{4}^{3-}, \mathrm{Co}^{2+}, \mathrm{Cu}^{2+}$ and $\mathrm{Ni}^{2+}$ are present, separation techniques such as employing masking and demasking agents must be used. 3-Hydroxy-3-m-tolyl-1-0-carboxyphenyltriazene which has fairly a wide range of $\mathrm{pH}$ compared to other hydroxytriazenes can be used in various applications.

\section{ETHICS APPROVAL AND CONSENT TO PARTICIPATE}

Not applicable.

\section{HUMAN AND ANIMAL RIGHTS}

No Animals/Humans were used for studies that are base of this research.

\section{CONSENT FOR PUBLICATION}

Not applicable.

\section{AVAILABILITY OF DATA AND MATERIALS}

The author confirms that the data supporting the findings of this research are available within the article.

\section{FUNDING}

None

\section{ACKNOWLEDGEMENT}

The author is grateful to Chuka University Management for allowing the author to use Chemistry facilities at the University. The author also expresses gratitude to Richard Kariuki Muya and Peace Kakuta for their contributions.

(C) 2020 Life Science Informatics Publication All rights reserved Peer review under responsibility of Life Science Informatics Publications 


\section{CONFLICT OF INTEREST}

The author has no conflict of interest.

\section{REFERENCES}

1. Maa $\beta$ P, Pei $\beta$ ker P. Handbook of Hot-Dip Galvanization. John Wiley and sons.2011.

2. Kreysa G, Schutze M. Corrosion Handbook: corrosive agents and their interactions with materials. John Wiley and sons.2009.

3. Chali E, Sastri VS, Elboujdaini M. Corrosion prevention and protection: practical solutions. John Wiley and sons.2007.

4. Streitberger HJ, Dossel KF. Automotive paints and coatings. John Wiley and sons.2008.

5. Sahoo P, Das SK, Davim JP. Surface finish coatings. Comprehensive material finishing. 2017; 3:38-55.

6. Hanawa T. Overview of metals and applications: metals for Biomedical Devices. Woodhead publishing series in Biomaterials. 2019:3-29.

7. Guannan L, Hongtao Y, Yufeng Z, Xie-Hui C, Jian-An Y, Donghui Z, et.al. Challenges in the use of zinc and its alloys as biodegradable metals: perspective from biomechanical compatibility. Acta Biomaterialia. 2019; 97:23-45.

8. Goodwin FE. Zinc and zinc alloys: kirk othmer Encyclopedia of chemical Technology. John Wiley and sons.2006.

9. Kainer KU. Magnesium alloys and their applications. John Wiley and sons.2000.

10. Kumar DS, Sasanka CT, Ravindra K, Suman KNS. Magnesium and its alloys in automotive applications: A review. American journal of materials science and Technology.2015; 4(1): 12-30.

11. Mohammad M, Ahmad OM and Mamoun M. Essential magnesium alloys Binary Phase diagrams and their thermochemical data. Journal of materials.2014:1-33.

12. Jun-xi T, Ming-chun Z, Ying-chao Z, Deng-feng Y, Long L, Chengde G, et.al. Influence of graphene oxide $(\mathrm{GO})$ on microstructure and biodegradation of $\mathrm{ZK} 30-\mathrm{xGO}$ composites prepared by selective laser melting. Journal of magnesium and alloys. 2020; 8(3):952-962.

13. Barbara AS. Corrosion resistance of magnesium alloys. Pennsylvania State University. 2003.

14. Annalisa P, Marialaura T \& Frank EG. Review of microstructures and properties of Zinc alloys metals. 2020; 10(253): 1-16.

15. Mohammad AB, Rebecca B \& Shamsui H. Estimation of Manganese, Zinc and copper in multimineral preparation containing vitamins: A Complexometric Approach. Stamford Journal of Pharmaceutical science. 2009; 2(2): 16-20.

16. Harlal C, Todd S, Joyce D, Lisa I, Mark O, Margaret F,et.al. Toxicological review of Zinc and Compounds (CAS NO.7440-66-6). U.S Environmental protection agency Washington DC. 2005.

17. Nguyen MT, Nguyen VH, Nguyen DL, Nguyen HP \& Tran TTT. Simultaneous Determination of $\mathrm{Zn}$ (II), $\mathrm{Cd}$ (II), $\mathrm{Pb}$ (II) and $\mathrm{Cu}$ (II) using differential pulse anodic stripping voltammetry at a

(C) 2020 Life Science Informatics Publication All rights reserved

Peer review under responsibility of Life Science Informatics Publications 
Bismuth film-modified electrode. Advances in material science and Engineering. 2019: 1-2.

18. Hafeez B, Mohd KY \& Muhammad S. Role of Zinc in plant Nutrition: A review. American Journal of Experimental Agriculture. 2013; 50(1):374-391.

19. Tsonko T \& Fernando JCL. Zinc in plants: An Overview. Emir.J.Food Agric. 2012; 24(4): 322-333.

20. Masoom RS, Zeid AA \& Nafisur R. Analytical techniques in pharmaceutical analysis: A review. Arabian Journal of Chemistry. 2013; 10: 51409-51421.

21. Mendham J, Denney R, Barnes JD \& Thomas MV. Textbook of Quantitative Chemical Analysis. Pearson Education Limited. 2000.

22. Colin GH \& Michael AL. Determination of Zinc in the presence of Copper, Cadmium and Lead by Photometric EDTA Titration with selective masking. Analyst.1987; 12:329-322.

23. Saba K \& Rehana K. Analytical Application of 3-Hydroxy-3-m-tolyl-1-m-chlorophenyltriazene as metallochromic indicator for Complexometric determination of molybdenum (IV). Asian Journal of Chemistry. 2009; 21(5): 4127-4129.

24. Khanam R, Sharma JC, Khan S, Dashora R, Chauhan RS \& Goswami AK. Complexometric Determination of Zinc (II) in pharmaceutical samples using Hydroxytriazenes. International of pharmaceutical sciences and Drug Research. 2010; 2(1): 43-44.

25. Shetty $\mathrm{P}$ and Shetty AN. A simple and rapid Complexometric Determination of Thallium (III) using Mercaptoethane as Demasking Agent. S.Afri.J.Chem. 2006; 59: 97-100.

26. Hikime S \& Gordon L. Precipitation of Zinc 8-Hydroxyquinaldate from homogeneous solution. Talanta. 1964; 11(5): 851-854.

27. Ombaka O, Musundi SW, Gitonga LK, Kibaara D, \& Olivia AN. Rapid Economical and Selective Complexometric determination of Iron (III) in its synthetic alloys using 3-Hydroxy-3-phenyl(2,4,6-tribromophenyl)triazene. International Journal of scientific and Engineering Research. 2013; 4(9): 140-145.

28. Khanam R, Sharma K, Khan S, Dashora R, Chauhan RS \& Goswami AK. Synthesis, Characterization and antifungal activity of 3-Hydroxy-3-p-tolyl-1-m-nitrophenyltriazene and its complex with iron (III). J.chem.pharm.Res. 2011; 3(6): 571-575.

29. Tomiko A, Yuki N, Noriko I, Masatsune M, \& Serichi H. Characterization of Zinc Chelating compounds in instant Coffee agricultural and Biological Chemistry. 1990; 54(4):855-862.

30. Jingying $Z$ and Eric B. Complexometric titrations: New reagents and concepts to overcome old limitations. Analyst. 2016; 141: 4252-4261.

31. Maria M and Francisco S. Understanding Complexometric titration of metal cations with a minopolycarboxylic Acid (EDTA and Analogs) within the frame of Notion of Reactions between groups of Chemical species. World Journal of Chemical Education. 2015; 3(1): 5-21.

(C) 2020 Life Science Informatics Publication All rights reserved Peer review under responsibility of Life Science Informatics Publications 